Article

\title{
Eroding Rights, Crafting Solidarity? Shifting Dynamics in the State-Civil Society Nexus in Flanders and Brussels
}

\author{
Robin Vandevoordt ${ }^{1,2, *}$ \\ ${ }^{1}$ Refugee Studies Centre, University of Oxford, Oxford, OX1 3TB, UK; E-Mail: robin.vandevoordt@qeh.ox.ac.uk \\ 2 Department of Sociology, University of Antwerp, 2000 Antwerp, Belgium
}

Submitted: 6 February 2019 | Accepted: 22 April 2019 | Published: 27 June 2019

\begin{abstract}
In 2015, hundreds of new civil initiatives emerged to provide stopgap help to refugees arriving in Belgium. This article zooms out from this moment of solidarity and explores the broader socio-political conditions that allowed these initiatives to emerge and, in some cases, solidify into professional service-providers or powerful political actors. The article focuses on two case studies, one in Flanders and one in Brussels. In Flanders, the Hospitable Network brings together local civil initiatives which have drawn upon the networks and skills of senior citizens with considerable experience in civic associations, NGOs and social movements. While these initiatives have partly filled the gaps that were created by a series of neoliberal reforms in Flanders' citizenship regime, the same neoliberal outlook has prevented these initiatives from being institutionalised. In Brussels, the Citizen Platform for the Support of Refugees has mobilised largely among the city's super-diverse population. The Platform's development has been shaped by Brussels' continuing attractiveness to immigrants, as well as by the city's complex governance structure, which has provided it with both material support and increasing opposition. As a result, the Platform has become a highly visible political actor offering partly professionalised support to refugees.
\end{abstract}

\section{Keywords}

asylum policies; citizenship regime; mobilization; refugees; social movements; solidarity

\section{Issue}

This article is part of the issue "The European Refugee Controversy: Civil Solidarity, Cultural Imaginaries and Political Change", edited by Gert Verschraegen (University of Antwerp, Belgium) and Robin Vandevoordt (University of Oxford, UK/University of Antwerp, Belgium).

(C) 2019 by the author; licensee Cogitatio (Lisbon, Portugal). This article is licensed under a Creative Commons Attribution 4.0 International License (CC BY).

\section{Introduction}

Since the summer of 2015 , citizens have established various initiatives to provide stopgap help to refugees arriving in Europe. While most research has focused on citizens' actions and discourses (Ataç, Rygiel, \& Stierl, 2016; della Porta, 2018; Feischmidt \& Zakaria, 2019; Youkhana \& Sutter, 2017), this article zooms out from these moments of solidarity, and explores the broader socio-political conditions that allowed these initiatives to emerge and, in some cases, solidify into professional service-providers or powerful political actors. I focus on two civil initiatives in particular: the Hospitable Network in Flanders and the Citizen Platform for the Support of Refugees in Brussels. In both cases I describe how the social backgrounds of its leading volunteers and the politi- cal environment in which they emerged, have impacted the way in which these initiatives have organised themselves, which strategies they use, and to what extent they have become institutionalised. More concretely, I argue that the Hospitable Network emerged in the context of neoliberal policy reforms, which provided an incentive for citizens to mobilise and oppose its institutionalisation. The Citizen Platform, however, exemplifies how superdiverse metropolises such as Brussels can be a place where new (fleeting) forms of solidarity can be crafted.

I substantiate these arguments by drawing on two types of data. First, I draw on desk-based research that includes an analysis of the secondary literature on Belgian citizenship regimes prior to 2015 , and a supplementary, primary analysis of recent policy documents and press statements by the actors involved. In these analy- 
ses, I focus on the relations between state and civil actors. Second, I analytically describe two case studies for which I draw on on-going ethnographic work, comprising both in-depth interviews and participant observation. In Flanders, I have worked with the Hospitable Network ("Gastvrij Netwerk"), a platform of 38 civil initiatives operating in local municipalities. The Hospitable Network organises board meetings, workshops and newsletters in which member initiatives exchange experiences and develop common strategies to support refugees. The support they provide responds to refugees' changing needs: finding housing, practising Dutch, children's homework, everyday administration, leisure and developing social contacts with established locals. In Brussels, I worked with the Citizen Platform for the Support of Refugees, which emerged in 2015 from the tens of thousands of citizens who offered stopgap help to refugees stranded in the capital. Over time, the Platform has developed into a volunteer-driven NGO that offers an array of services to forced migrants, irrespective of their legal status. These include both general social services (e.g., language classes, socio-administrative advice) and humanitarian assistance (e.g., shelter, food, clothing).

My on-going ethnographic work with both initiatives has taken a variety of forms. In the Hospitable Network I have participated in general assemblies, national workshops and the activities of some of its local member groups. I have also conducted seven in-depth interviews with the Network's leading volunteers, focussing on its rise, organisational development and its relations with state actors. In the following months I will conduct interviews with individual volunteers from the Network's member organisations. In the Citizen Platform, I have participated as a volunteer in its various social and humanitarian services, and in a wider range of actions such as demonstrations, workshops and social events. While I am still conducting interviews at the time of writing, I have to date conducted 14 interviews with its coordinators (5) and individual volunteers (nine).

In the next section, I first develop a conceptual framework, to explore the conditions that allowed these initiatives to emerge and have shaped their development over time.

\section{Social Networks, Political Opportunities}

Both the Hospitable Network and the Citizen Platform strive towards a dual goal: to provide basic humanitarian and social services to a diverse group of forced migrants; and to induce broader cultural and political changes to improve forced migrants' living conditions. Only the latter makes them a social movement in the strict sense (cf. Jasper, 2014). Although I therefore think we should explore, rather than assume that these civil initiatives represent a nascent social movement (Vandevoordt, in press-b; cf. Melucci, 1989), this article makes use of key concepts in social movement studies. I do so for two reasons. First, a large part of the recent scholarly work on civil initiatives supporting refugees has been firmly situated within this literature (e.g., Ataç et al., 2016; della Porta, 2018; Pries, 2018). To link this article to these debates, it makes sense to use a similar conceptual framework. Second and more importantly, social movement studies provide us with concepts that are useful to analyse how these initiatives develop over time. I draw on two concepts in particular: the social networks and skills of the movements' (leading) participants, and the political opportunity structures (POS) in which they emerge. Focusing on these two notions will help us understand how these civil initiatives have organised themselves, which strategies they use to achieve their goals, and the extent to which they are able to become institutionalised as social and/or political actors.

First, from earlier studies we know that newly emerging movements mobilise participants through existing social networks (Diani \& McAdam, 2003; Snow, Zurcher, \& Ekland-Olson, 1980). This was the case for many European civil initiatives supporting refugees in 2015. In Germany, for instance, scholars have documented that $34 \%$ of the volunteers providing stopgap help to refugees in 2015 had been involved in volunteering work with refugees prior to 2015 (Karakayali \& Kleist, 2016). Similarly, Pries (2018) has argued with respect to Germany and Spain that the civil initiatives supporting refugees during and after 2015 have built strongly upon an existing body of NGOs and civic associations.

What interests me in this article, however, is how individuals' embeddedness in social networks shapes the way in which these civil initiatives work. To refine this question I draw on Jasper's $(1997,2014)$ biographical approach, which focuses on the skills participants have acquired in previous social contexts. ${ }^{1}$ According to Jasper (2014), for instance, the rise of the women's movement in the US was partly driven by women who had participated in the student and peace movements a few years before. There they had learned how to embed their local organisations into national networks, how to organise symbolic protests and how to translate everyday experiences into policy demands. In a similar vein, drawing attention to individuals' previous social networks can help us understand three things about recently emerging civil initiatives supporting refugees: how do they organise themselves? Which strategies do they deploy? And which approach do they develop in supporting refugees?

Second, scholars have increasingly focused on movements' POS: the external political environment in which they arise, develop and have institutionalised themselves (e.g., Tarrow, 2011). Two factors are of particular

\footnotetext{
${ }^{1}$ Within the sub-strand of "resource mobilization theory", individual skills have also been understood in terms of "human and cultural resources" (Edwards, McCarthy, \& Mataic, 2018). In this article, however, I draw upon Jasper's $(1997,2014)$ conceptualisation, largely because his meaning-centred cultural-sociological approach fits better with the overall scope of my ethnographic work than the rationalist assumptions underlying the "resource mobilisation" paradigm. Admittedly, for this article both approaches would have been suitable.
} 
importance to our purpose: the relation between state and civil actors, and the needs that are created by specific policies. To begin with the former, it is crucial to note that Belgium has a long tradition of corporatistdemocratic decision-making, in which civic associations are closely involved in the organisation of the welfare state, both as service-providers and as partners in political decision-making. In this sense, municipal, regional and federal governments may offer resources for civil initiatives to professionalise their services and institutionalise their position as a formal organisation. However, various Belgian state actors have recently moved away from this corporatist model towards a model of neoliberal governance, thereby limiting civil actors' role in decision-making (Van Puymbroeck \& Saeys, 2014). How has this context, then, influenced the development and institutionalisation of these civil initiatives?

A second factor of POS concerns the needs that have been (in)directly created by specific policies. One of the more pertinent critiques that has emerged with respect to civil initiatives supporting refugees, is that they fill the gaps that were created by their national governments (Van dyk \& Misbach, 2016). This brings us to the following question: in which ways were the needs citizens sought to address a consequence of broader developments in Belgium's asylum and integration policies?

\section{A Brief History of Belgian Integration Policies}

In this section I sketch some of the broader developments in recent Belgian integration policies. I concentrate on the POS these policies created, in the twofold sense of the relation between state and civic actors, and in creating immigrants' needs that were later addressed by civil actors. First, however, it is useful to note that Belgium has an exceptionally complex constellation of migration and integration policies (Martiniello, 2013). While the Federal government is responsible for most matters relating to migration, such as nationality procedures, deportation and asylum, the Regional governments of Flanders and Wallonia are responsible for the integration of immigrants, which includes organising civic integration and language courses, and ensuring access to education, work, housing and health care. To make the situation even more complex, Belgian municipalities have a relatively high degree of autonomy vis-à-vis their Regional and Federal counterparts in deciding whether and how they take initiatives in ensuring migrants' access to housing, work and education.

Like many Western European countries, Belgium's recent immigration history began with the arrival of Mediterranean "guest workers", which reached its zenith in the 1950s and 1960s. As consecutive governments expected these "guest workers" to return to their countries of origin, most of the social support came from citizens. The latter organised language classes, helped to find accommodation, set up leisure associations, and helped to establish the first mosques (Goeman \& Van Puymbroeck, 2011; Groffy \& Debruyne, 2014). For a long time, the reception of migrants in Belgium was thus characterised by a lack of coherent political vision on integration, asylum and migration. This created opportunities for citizens to take action and organise things themselves.

In the 1980s several Belgian governments began to develop integration policies. In this period the Belgian state underwent a process of devolution, in which policy domains that were previously a competence of the Federal state, such as integration, were transferred to the Regional governments of Flanders and Wallonia (Adam, 2013). In Flanders, these developments began after the electoral breakthrough of the extreme-right Vlaams Blok in 1988. In response to this perceived integration crisis, the Flemish government created long-term project funds for civil initiatives and municipal governments develop local integration policies. In line with Belgium's general political tradition of corporatist-democratic cooperation, civil and state actors collaborated closely with one another as more or less equal partners. Civil actors were granted considerable autonomy in setting priorities, building a vision and establishing an organisational structure. Throughout the 1990s, their services gradually became more professional and specialised. In Flanders, for instance, 43 local and eight regional integration centres were established, as well as four Dutch language houses and four Social translation centres (Groffy \& Debruyne, 2014). The dominant vision that emerged in Flanders ${ }^{2}$ somewhat resembled the multicultural policies that had long been central to integration policies in the Netherlands, in which social support was organised along the lines of different migrant groups, depending on their nationality, religion and gender.

In Brussels, a different, more complex situation has emerged. This has partly been the result of a policy gap, as the Brussels Region does not have jurisdiction over integration. Instead, migrants in Brussels can choose to comply either with Flemish or Walloon integration policies, both of which are ill-adapted to the super-diverse context of Brussels, which is similar to other metropolitan capitals such as Paris and London (Bousetta, Favell, \& Martiniello, 2018). As a result, the pressure to deal with the capital's super-diversity has been largely left to Brussels' 19 municipalities and its large battery of civic associations. Some of these municipalities have furthermore seen a rapid diversification since the 1980s, creating minority-majorities (i.e., where the majority of inhabitants have a migration background). Especially in poorer and super-diverse municipalities such as SintJans-Molenbeek and Anderlecht, this has contributed to

\footnotetext{
${ }^{2}$ The main difference between Flemish and Dutch multiculturalism was that in Flanders these policies emerged from bottom-up civil initiatives, which were subsequently incorporated into government policies, whereas those in the Netherlands were largely installed top-down by the central, national government (Adam, 2013). In Wallonia, a non-interventionist policy developed which rather resembled the French, Republican model: the integration of newly arriving migrants was not seen as requiring a separate competence, but as an aspect of mainstream institutions and policies such as education, work, and welfare.
} 
a relative dominance of left-leaning, inclusive social policies that have been more favourable to a "soft" stance on integration (Bousetta et al., 2018). In these municipalities, the persistence of strong connections between socialist civic associations and the still-dominant Parti Socialiste have fed into an exceptionally high concentration of professional and non-professional civic associations, even by Belgian standards (Swerts \& Oosterlynck, 2018). In addition, despite its lack of formal powers to deal with integration, the Brussels Region has supported civil actors such as Samu Social, Vluchtelingenwerk and Ciré, which are either directly or indirectly active in the field of integration. In sum, Brussels has been characterised by a complex multilevel governance structure, that both created a gap in coherent integration policies and a range of opportunities for civil initiatives to secure funding and operational autonomy.

In Flanders, however, the continuing growth of the extreme right fed into criticism of Flanders' fragmented multiculturalist policies. According to critics, the field of integration was characterised by an unmanageable proliferation of civil and state actors offering overlapping services and embodying contradictory visions on integration (Groffy \& Debruyne, 2014). Fuelled by European critiques on the failure of multicultural policies, the Flemish government adopted a series of measures that gradually replaced its 'cooperative multiculturalism' with a neo-liberal, neo-communitarian citizenship regime that shifted power from civil actors to the state (Van Puymbroeck \& Saeys, 2014). This development culminated in a controversial reform of the integration sector in 2014, which centralised a wide range of social services into a single agency that would develop a more coherent vision. The local and provincial centres for integration, social translation and legal advice that had emerged from civil initiatives, were thus merged into a single government-controlled Agency of Integration and Citizenship ('Agentschap Inburgering en Integratie'; Groffy \& Debruyne, 2014; Van Puymbroeck \& Saeys, 2014).

On a national level, the establishment of the Flemish Agency of Integration and Citizenship was the result of a dual process of Flemish state-building (Adam, 2013) and nation-building (Martiniello, 2013). As the Belgian state increasingly shifted competences towards the Flemish region, the Agency of Integration and Citizenship took on a task that seemed particularly crucial to nurturing Flanders' supposedly homogenous culture. The major developments in Flemish integration should therefore be seen against the backdrop of a programme of regional state and nation-building.

From a broader perspective, these reforms were driven by the rising popularity of neoliberal discourses across the European continent. These elements are of crucial importance here. On the one hand, neoliberal state actors both withdraw from, and expand their grip on society: state actors reduce support to civil actors and demand more control over the work of those actors it continues to support. As a result, civil actors are seen as contracted service providers, rather than political partners with considerable autonomy. Moreover, these neoliberal discourses have tried to make migrants responsible by rendering their social rights conditional upon their achievements (Joppke, 2007; Schinkel \& Van Houdt, 2010). Until 2013, the Flemish state mostly conceived of integration as a two-way process requiring both migrants and the established communities to shoulder their responsibilities. From 2014 onwards, the emphasis shifted towards "civic integration" or "citizenisation" (Inburgering), in which it was primarily migrants' responsibility to prove their cultural assimilation and economic self-reliance (Groffy \& Debruyne, 2014). In order to retain certain social (e.g., social housing, social benefits) and civic rights (e.g., family reunification, naturalisation), immigrants were now obliged to prove their proficiency in Dutch and their prior independence from benefits. Despite the specifically national context of Flemish state and nation-building, these developments can thus be situated in a broader converging trend in European integration policies (cf. Joppke, 2007; Schinkel \& Van Houdt, 2010).

Summing up, Belgium has long been characterised by a lack of coherent integration policies. Since the 1980s, different integration policies have developed in Flanders and Wallonia, which created a policy gap in the Region of Brussels. In Flanders, the initial model of 'cooperative multiculturalism' was gradually replaced by neoliberal policies that reduced the social and political role of civil actors, and gradually eroded migrants' social rights. In Brussels, the pertinent policy-gap and the growing super-diversity of its population have fed into strong collaborations between state and civil actors, with the latter playing a crucial role in the support of newly arriving migrants. In the following sections I describe how these broader contexts have shaped the responses of civil actors to the 2015 "asylum crisis" and its aftermath.

\section{The 2015 Reception Crisis and Its Aftermath}

In Belgium, the increased arrival of refugees in 2015 manifested itself most clearly in the emergence of a spontaneous camp in the Maximilian Park, where citizens provided all kinds of humanitarian, social and political support (Depraetere \& Oosterlynck, 2017; Lafaut \& Coene, 2018; Vandevoordt \& Verschraegen, 2019). In this article, however, I will not focus on this initial moment of mobilisation, but on the long-term mobilisation of the Hospitable Network and the Citizen Platform. The acute crisis of 2015 developed into two distinct crises in Flanders and Brussels, both of which have shaped how these initiatives have organised themselves. In Flanders, a slower integration crisis emerged, which centred around affordable housing. In Brussels, the Citizen Platform was confronted with a more volatile situation, as migrants of different legal statuses continued to arrive in and around the Maximilian Park. 


\subsection{A Slow Burn: Flanders' Integration Crisis}

In this section I describe three factors that have shaped the rise and development of the Hospitable Network: the immediate needs created by the 2015 asylum crisis and its aftermath; the social backgrounds of its leading volunteers; and the long-term POS in which it operates. Together, these factors reveal a complex image of the Network, caught by two paradoxes. While the Network was able to emerge due to neoliberal policies that created the need to take action, the same neoliberal policies have made it difficult to institutionalise their efforts. Similarly, while the Network's leading volunteers were equipped with the skills to address the structural causes of refugees' problems and engage in political dialogue, the rather hostile political environment of the Flemish government put them in a position where they were inadvertently filling the gaps created by Flanders' neoliberal integration policies.

To understand how and why civil initiatives in Flanders emerged, it is crucial to take into account how asylum seekers are accommodated in Belgium. Since the early 1990s, the Federal government has gradually developed a twofold accommodation system coordinated by Fedasil, a government agency established for this very purpose. First, Fedasil coordinates a network of collective reception centres, some of which are managed by Fedasil, and some of which are managed by the Red Cross. Second, Fedasil coordinates a network of Local Accommodation Initiatives (LAIs), which are usually managed by municipalities' social services. When the number of asylum seekers rapidly rose in the summer of 2015, the Federal government established emergency reception centres in places such as abandoned military barracks, bungalow parks and pontoons, thereby creating an additional 15,000 places (Fedasil, 2016). As early as 1 September 2015, the Federal government urged municipalities to create more LAls: an additional 1,010 LAls therefore became operational by the end of 2015, and 2,151 more by the end of 2016 (Fedasil, 2015, 2016, 2017).

These LAls, and, to some extent, the emergency reception centres, proved of crucial importance to the mobilisation of citizens across Flanders. These additional places for accommodation brought asylum seekers into smaller municipalities, which provided citizens with an opportunity to mobilise themselves locally. This policy measure also had a decisive impact upon the type of support these initiatives provided. Their work concentrated largely on the local integration of refugees as they passed through the asylum system: first as asylum seekers residing in LAls, and second as either refugees who had receiving protected status, or as undocumented migrants whose asylum applications had been rejected. Hence, they helped refugees to find housing, practice their Dutch, support school-going children, organise women's groups, introduced them to leisure associations and organised socio-cultural events to strengthen their net- works. In other words, these emergency reception measures created a favourable political opportunity structure for citizens to become involved, because it provided them with both a point of contact with local state actors (the municipal social centres organising the LAIs) and with a situation in which their help was needed (i.e., everyday social support for asylum seekers).

Second, the Hospitality Network has been strongly shaped by the networks and skills of its leading protagonists. Most of its leading figures are senior men and women who had recently retired, and who had spent a large part of their lives in a variety of civil organisations and networks. A small but significant number had been active in NGOs supporting migrants since the 1980s, either professionally or voluntarily. Others had been members of local branches of the North-South movement, a so-called "new social movement" which arose in the late 1960s and was institutionalised in the 1980s and 1990s (Walgrave, 1994). Yet others had been active in one of the many associations related to the "pillars" of Belgian civil society, including socialist and Catholic labour unions, and socio-cultural, women's and youth associations.

Citizens' firm roots in organised civil society had a decisive impact on their approach. Most importantly, they tried to avoid merely offering ad hoc assistance to refugees, preferring to work structurally instead. This had been a defining feature of the three types of civil organisations they had previously participated in. Since its radicalisation in the late 1960 s, the North-South movement had strongly set itself apart from charitable forms of development aid. Instead, their fundraising actions, awareness-raising campaigns and political interventions were rooted in a critical political economic perspective on Northern countries' responsibilities in producing Southern poverty (Walgrave, 1994). Similarly, the civil initiatives that emerged to support the "guest workers" in the 1960 and 1970s and the first groups of refugees in the 1980s, had developed an increasingly structural approach due to their professionalisation in the 1990s. In this period, they moved away from a perspective centred on individual well-being, towards one focused on broader issues such as access to work, housing and education (Groffy \& Debruyne, 2014). And lastly, the civic associations in which many of the Network's leaders had participated, were also characterised by a long-term embeddedness within the broader environment of Flanders' socialist and Catholic pillars (cf. Walgrave, 1994).

The Hospitable Network operated in much the same way. Most of its member initiatives did not emerge from the spatial setting of a pending humanitarian crisis, but from a call among active locals to attend a board meeting, to explore what they could do for refugees, how they could best achieve this, and with which other actors they could cooperate. In line with Belgium's tradition of corporatist-democratic cooperation, most initiatives thus immediately tried to establish contact with local municipalities and their social services, as well as with local 
NGOs focusing on poverty and other forms of exclusion. In many instances, this resulted in the launch of (new) working groups on refugee support, in which both the emerging civil initiative, the municipality's social workers and other NGOs participated. In addition, most of these initiatives not only provided support to refugees, but also tried to influence local policy-makers by writing memoranda and organising meetings to address barriers to refugee inclusion. Most initiatives also tried to reach out to local citizens by raising awareness of refugees' stories, and by organising socio-cultural events to establish personal encounters. In this sense, the social networks of its leading volunteers and the skills and visions they had developed there have had a crucial impact on how they mobilised, how they engaged with state actors, and on their structural approach to addressing refugees' problems.

So what were the more structural problems these civil initiatives encountered? First and foremost, in Flanders, the 2015 reception crisis slowly fed into a more long-term housing crisis. In contrast to countries such as the Netherlands and Germany, asylum seekers in Belgium are only offered accommodation during their asylum procedure. There are no state agencies responsible for coordinating refugees' transition into the regular housing market. As soon as they have received a positive decision on their application, refugees need to find accommodation by themselves within two, or a maximum of four months. Most struggle to do so, for several reasons: they have limited social networks, do not know the language or the local housing market and its administrative procedures, they have no steady income and are often faced with racial and religious discrimination. In addition, the Belgian housing market is characterised by a high degree of property ownership and a shortage of cheap rental accommodation (Saeys, Vandevoordt, \& Verschraegen, 2018).

From the moment refugees receive protected status, they are entitled to municipal social services, which includes a living allowance. In principle, however, they need to be residents of a specific municipality before they can apply for the material or social support it provides. This means that it is up to the municipality's social services to decide whether or not they will assist newly arriving refugees. And as some municipalities have attempted to discourage migrants from settling on their territories, most refugees became dependent upon their own social networks, civil initiatives and NGOs to find housing (Saeys et al., 2018).

While the root causes of Belgium's housing crisis are endemic to both its housing market and the organisation of refugees' accommodation, they can also be seen in relation to the neoliberal reforms in recent years. Before the 2014 reform, for instance, around 50 centres for integration were embedded in Flanders' municipalities and provinces, from where they addressed immigrants' structural barriers to inclusion. The reform, however, had shifted its attention away from these structural barriers, had dismantled the local connections of these integration centres and concentrated more on migrants' own responsibilities. When these civil initiatives set out to focus on refugees' structural exclusion on a local level, it looked very much as if they were filling a gap that had been created by the 2014 reform. In this sense, the reform created POS that were favourable to civil mobilisation, as it indirectly created a gap in social support which seemed necessary for refugees' inclusion in central social institutions.

Apart from ensuring refugees' access to the housing market, these initiatives tried to connect refugees to Belgian society in the broader sense. They concentrated on the everyday needs of refugees, for which professional social workers lacked time to provide support: they accompanied them on trips to lawyers to translate between legal jargon and refugees' complex stories; helped them find their way in Belgian bureaucracy; offered homework support to children; organised events where women, men and young people could diversify and strengthen their social networks; used their own networks to find opportunities for work and helped them to apply for jobs; personally introduced refugees into civic associations to develop their interests (e.g., music school, sports club, etc.); and organised socio-cultural activities to help them meet up with locals. All of these activities had been the core business of the civil initiatives that arose prior to the 1990s and then were institutionalised into a wide range of local integration centres.

The same neoliberal discourse that produced the need (or opportunity) for these initiatives to arise, however, also prevented their institutionalisation. Between 2016 and 2018, Flemish Minister of Home Affairs Liesbeth Homans created a fund of 20 million euros for the local integration of refugees (Deprez, Platteau, \& Hondeghem, 2018). By allocating these funds to municipalities instead of to the civil initiatives-which had, in many instances, not only taken the lead in refugee support, but also had better connections and expertise to do so, given that most rural municipalities had little if any experience in working with immigrants-Homans continued the long-term trend of shifting power from civil actors to the state. In contrast to the civil initiatives that arose in the 1970s and 1980s, this generation of initiatives had fewer opportunities to professionalise their work. To put it differently, the neo-liberal outlook of the Flemish government-which saw civil actors as potential service-providers that could be contracted by state actors, rather than equal social partners-thus produced a political opportunity structure that encouraged the emergence of civil initiatives but was hostile towards their institutionalisation.

In addition, the Federal government's restrictive stance towards immigration also had a negative impact on citizens' opportunities to mobilise. In the summer of 2018, State Secretary of Asylum and Migration Theo Francken announced a substantial reduction of the reception capacity for asylum seekers, which tilted the balance of the reception network back to collective recep- 
tion centres, instead of LAls. Nine temporary reception centres were closed down (i.e., 2,854 places), while the number of places in LAls were reduced by 3,600 (Fedasil, 2018). This decision was informed by Francken's earlier attempt to establish a two-tiered asylum system: a fasttrack to local integration for refugees who were either vulnerable or were very likely to be granted asylum, and who would be accommodated in LAls (e.g., Syrians), and a slow-track for others, who would be accommodated in collective reception centres. Several of the Hospitable Network initiatives protested against these decisions. According to them, the expertise and networks they had established in close collaboration with municipal social services and local schools, hospitals and leisure clubs would be lost if these LAls were closed. Put differently, this shift from individual to collective accommodation is likely to have a negative impact on citizens' mobilisation for refugees, as the LAls, specifically, had provided them with an opportunity to set up local initiatives to become involved in the first place.

To sum up, the neoliberal policy shift of the Flemish government created opportunities for civil initiatives to mobilise but made it difficult for them to institutionalise their work. And while the Hospitable Network's leading volunteers tried to take structural action and engage in political dialogue, they did so in a political climate that seemed rather hostile towards cooperation.

\subsection{A Blazing Fire: Brussels' Recurring Humanitarian Crisis}

The Citizen Platform was one of the first initiatives to arise from the spontaneous refugee camp in the Maximilian Park, in an attempt to coordinate citizens' actions. Initially, citizens provided mainly humanitarian support (shelter, food, clothes, washing facilities), yet as Brussels continued to attract refugees before, during and after their asylum procedure, the Platform gradually expanded its range of services. In this section I describe three factors that have shaped the development of the Platform: Brussels' continuing importance to immigrants; the city's super-diverse pool of volunteers; and its complex multilevel governance structure. Together, these factors have turned the Platform into a highly visible political actor, offering partly professionalised support to forced migrants.

First, Brussels has repeatedly been the primary site in which Belgium's reception crises have manifested themselves. As I noted in Section 4, in 2015 the Federal government's failure to organise accommodation for asylum seekers created an opportunity for citizens to mobilise in and around Brussels. In the summer of 2017, a new development led the Citizen Platform to expand its range of activities, enlarge its pool of volunteers, and develop a more radical political voice. An increasing number of migrants arrived in Brussels, most of whom could not or preferred not to apply for asylum in Belgium. Some had had their fingerprints taken in other European countries such as Italy, Greece or Hungary, where they either did not want to apply for asylum, or where they had applied for asylum and were appalled by refugees' living conditions in those countries (Médecins Sans Frontières, 2019; Vluchtelingenwerk Vlaanderen, 2019). Others were determined to reach the U.K. and had been forced to flee the dismantled camps of Calais, Dunkirk and Paris. In Belgium, as in France, these migrants were increasingly targeted by police actions to arrest and deport them (Médecins du Monde, 2018). And because they preferred not to apply for asylum, they were excluded from most institutional support provided by municipal services and established NGOs.

As the Platform's volunteers saw that there were many minors, women and persons with urgent medical needs among them, they responded by setting up two lines of action, both of which drew heavily upon their earlier experiences in 2015. First, the Platform reinforced its partnerships with Médecins du Monde, Médecins Sans Frontières, the Red Cross and Oxfam International. In close collaboration, they established a humanitarian hub in the vicinity of the Maximilian Park, where they offered phone services, food, clothes and medical and mental health care (Vluchtelingenwerk Vlaanderen, 2019). Second, the Citizen Platform developed a twofold system of shelter, offering migrants a bed for the night. In response to an emergency call by the Platform's coordinators in August 2017, individual volunteers took the most vulnerable migrants into their homes. While this was intended as a one-time emergency measure, a series of controversies emerging around State Secretary Francken continued to "shock" new citizens into joining the Platform's group of volunteering hosts (Jasper \& Poulsen, 1995). The Platform's coordinators estimate that around 8,000 volunteers hosted migrants in their homes at least once between August 2017 and March 2019. As a result, between 20 and 600 migrants have been hosted in volunteers' homes for nearly every single night (Vandevoordt, in press-a). In this sense, the Citizen Platform emerged in response to urgent needs for shelter and humanitarian support that were created partly by Federal policy developments: the failure of this policy to provide adequate accommodation for asylum seekers in 2015, and the decision to persecute and exclude a group of migrants who could not or preferred not to apply for asylum in Belgium.

A second factor shaping the Citizen Platform is the pool of potential volunteers it draws upon. In contrast to the 'Hospitable Network', the Platform is driven by an ethnically and demographically diverse group of members, including migrants of different generations and backgrounds, (international) students, as well as professional expats and their children. This diversity has helped to create a cosmopolitan vibe that attracts a variety of people with a shared interest in this type of environment. At the same time, the Platform has faced a high turnover of volunteers and coordinators. This is partly because much of the work they do is emotionally taxing, and because of a widespread sense that they are continuously 
operating in a crisis mode of urgent humanitarian support, since otherwise migrants sleep out on the street without any adequate legal information, medical care, food or clean clothes. Continued absence of government action and difficulty for professional NGOs to take action creates a large burden on the Platform's volunteers, especially its more committed, driven volunteers. In addition, many of its volunteers are young people, students and expats who do not have a long-term connection to Brussels. As a result, many volunteers engage in a form of volunteering that is associated with liquid modernity: it is flexible and tailored to their schedule and renewed (social) experiences take priority over long-term engagement focussing on structural solutions-as is the case in the Hospitable Network. After a brief but intense period of volunteering at the Platform, students and expats, for instance, frequently return to their home countries, move elsewhere, or find a job. Every time I visited one of the Platform's social services to help as a volunteer, I encountered "newer" rather than "established" volunteers.

This fluid, continuously renewed pool of volunteers has contributed to the Platform's fluid organisational structure. Two aspects are particularly important here. On the one hand, practical organisation of the Platform takes place via Facebook, rather than through more formalised meetings, as was the case in the Hospitable Network (Vandevoordt, in press-a). Available volunteers are matched to specific services through polls on closed Facebook groups. This allows the Platform to attract volunteers who are currently available, and it allows volunteers to take up shifts that fit their agenda, regardless of their plans in the longer term. On the other hand, this Facebook-based set-up means that the Platform can call on its members to take immediate action. When new crisis situations emerge, the Platform is often able to act more quickly than government agencies, professional NGOs and other civil initiatives. When the Platform's core volunteers saw an increasing number of youths and women roaming around the Maximilian Park, for instance, they immediately and successfully appealed to their broader pool of volunteers to provide shelter. In this sense, Brussels' super-diverse demographic situation and the generally cosmopolitan outlook many of its inhabitants share, seem to provide the Platform with a large, continuously self-refreshing pool of available volunteers. As a result, the Platform's modus operandi is to take action first, and reflect on structural solutions second. This contrasts with the Hospitable Network, which emerged from established social networks and which centred its approach around identifying structural needs before taking concrete action.

So far, we have seen how the Citizen Platform has been shaped by its specific setting in Brussels, which provided it with both a site of repeated crises and with a constantly refreshed pool of volunteers. A third factor shaping the Platform is the POS produced by Brussels' complex multilevel governance structure. As the Platform's coordinators did not think their dual shelter system was sustainable in the long run, they lobbied the Municipal, Regional and Federal governments to establish an emergency shelter where migrants could receive basic medical care and legal-administrative information. While the Platform did not manage to convince these governments to establish such a centre, they did secure enough support to open such a centre themselves. The so-called Porte d'Ulysse opened in December 2017 and gradually expanded its capacity from 80 to 350 beds. Some of Brussels' 19 municipalities provided cleaning and washing services, while the Brussels Regional government covered the costs of renting an empty wing of an office building in Haren, in the outskirts of the city. In May 2018, the Regional government increased its support, enabling the Citizen Platform to temporarily employ around 20 full-time staff members, most of whom had been longstanding volunteers (Vandevoordt, in press-a). This allowed the Platform to gradually make its services more professional and become less dependent upon individual volunteers. Summing up, it was the Brussels multilevel governance structures, and its longer tradition of close collaboration between state and civil actors, which provided the Citizen Platform with the political support they needed to professionalise their services. In this sense, they found themselves in a local political opportunity structure that was favourable to their institutionalisation.

In spite of the local support, the Platform also faced increasing opposition from the Federal government, which intensified its attempts to detain and deport precisely those undocumented migrants the Platform seeks to support. This has led the Platform to engage in more assertive political action, mainly in the form of demonstrations, press statements and symbolic actions. Two measures in particular have encouraged this polarisation. First, on 30 June 2017, Federal Minister of Home Affairs Jan Jambon submitted a draft law that would make it possible for police forces to enter private properties if there are suspicions that undocumented migrants are residing there. In January 2018, however, this draft law became the subject of an intense public debate. Judges and legal scholars expressed their concerns that the law did not provide enough checks and balances to guarantee migrants' rights. Among both the government's liberal parties, resistance arose to the fact that properties belonging to third parties-i.e., persons with whom undocumented migrants were staying, including Platform volunteers-would also be subject to such house search warrants. In response, the Citizen Platform aligned with allied NGOs to organise demonstrations, press statements and a nation-wide campaign writing letters to local mayors, asking them to declare that they would not implement this law if it were to be adopted at Federal level. Ultimately, the law was abandoned due to both internal divisions in the Federal government's liberal and conservative coalition partners, and to broader public criticism.

Second, in January 2018, the Federal government stepped up its actions to arrest both undocumented mi- 
grants and human traffickers. In June 2018, the Federal public ministry charged eleven persons with human trafficking, including four who had hosted undocumented migrants. This lawsuit attracted considerable media attention and was interpreted as an attempt to undermine the image of the Citizen Platform as moral heroes (cf. Jasper, 2014). Through the lawsuit and the continuous discourse of leading political figures such as Theo Francken, Jan Jambon and Bart De Wever, the Citizen Platform was portrayed as an "extreme-left" movement flirting with the boundaries of the law-even though its hosting volunteers in particular tend to refer to care, humanitarianism and solidarity to distance themselves from politics as a whole (Alcalde \& Portos, 2018). While the four hosts were ultimately cleared of all charges, the lawsuit did seem an attempt to undermine the Platform's ability to host undocumented migrants, and to equate it with a radical, extremist movement. As a result, the Platform increasingly adopted a more assertive political voice, both in public and among its members. In this sense, it is uncertain to what degree the Federal government will be able to create a hostile environment for the Citizen Platform, and to what extent the Platform will further radicalise its actions to defend its work.

To sum up, the Citizen Platform has been strongly shaped by the specific context in Brussels. It has responded to a series of crises affecting the capital, which were partly produced by the policy gap in organising the arrival of new immigrants to Brussels. The city's super-diverse, sometimes temporary population has provided the Platform with a constant source of new volunteers. Both these developments have fed into a fluid, Facebook-based organisational structure, which has had a crucial impact on how the Platform has been organised (Vandevoordt, in press-a). And lastly, Brussels' complex governance structure has provided the Platform with both material support and increasing opposition. As a result, the Platform has become a highly visible political actor offering partly professionalised support to refugees.

\section{Conclusions}

This article has argued that the civil initiatives that arose in response to Europe's 2015 asylum crisis need to be understood in the context of broader political developments. In Belgium, two different crises arose in Flanders and in Brussels, which have been met with different forms of civil solidarity. In Flanders, a slow crisis unfolded, regarding local integration and housing. Crucial local opportunities to mobilise were created by the establishment of LAls and emergency reception shelters across the region of Flanders. In response, civil initiatives arose to provide support to refugees throughout their asylum procedure. Internally, the Hospitable Network has built on the remnants of older civic organisations in Flanders' North-South movement, its faith-based and political pillars, and the NGOs supporting migrants in the 1990s and early 2000s. In line with this civic heritage, the Hospitable
Network's member initiatives have tried to work structurally, rather than focusing on ad hoc assistance to individual refugees. While some of the challenges refugees faced were created by structural problems in the Belgian housing market and the system of accommodation for asylum seekers, these challenges were also generatedor exacerbated at the very least-by a series of neoliberal reforms in preceding years. As a result, local support services to immigrants had been both centralised and reformed, with a greater emphasis on immigrants' responsibilities. In that sense, the emergence of local civil initiatives attempting to include refugees more structurally seemed to fill a gap created by these neoliberal reforms. At the same time, however, this neoliberal outlook prevented them to institutionalise their services, as it meant that neither the Flemish nor the Federal government provided long-term support to the Hospitable Network and its member initiatives. As a result, the Flemish civil initiatives supporting refugees have remained a set of loosely connected fragments, each operating as a voluntary association in a distinct local environment.

The Citizen Platform, by contrast, found several opportunities to mobilise and partly professionalise their work in the specific urban context of Brussels. The presence, persecution and institutional exclusion of undocumented migrants created a recurring humanitarian crisis to which the Platform responded. To do so, they acquired structural support from several Brussels Municipalities and its Regional government. Lastly, the superdiverse, metropolitan nature of Brussels provided them with a continuously renewed pool of volunteers and coordinators coming from a variety of backgrounds. On the other hand, however, the Platform has faced increasing opposition from the Federal government, which not only stepped up its efforts to detain and deport undocumented migrants, but also tried to undermine citizens' attempts to support them, both legally and symbolically, by portraying the Platform as a radical movement balancing on the borders of legality.

So what do these two case studies tell us about the broader developments of civil initiatives for supporting refugees? On the one hand, these cases show us the significant impact of local circumstances. For both the Hospitable Network and the Citizen Platform, the POS provided by their respective municipal, regional and national governments have played a crucial role in their rise, their development, and the degree to which they institutionalise themselves. Furthermore, the social backgrounds of their leading volunteers have had a crucial impact on the strategies they use to work with state actors, the approach they develop in helping refugees, and how they organise themselves internally.

On the other hand, these case studies also point to two broader developments in refugee support in Europe. First, despite the persistence of national differences, in recent decades European integration policies have tended to converge to a neoliberal model. Migrants are being made responsible by rendering their so- 
cial rights conditional upon their achievements (Joppke, 2007; Schinkel \& Van Houdt, 2010; Van Puymbroeck, Blondeel, \& Vandevoordt, 2014), while state actors leave less room for (corporatist) cooperation with their civil counterparts. In regions such as Flanders, this has created a political environment that stimulates civil actors to take action in support of refugees, but which makes it harder for their work to become institutionalised. In this sense, eroding migrants' rights and fostering civil solidarity appear as two sides of the same coin. Second, in the last few years a burgeoning literature has emerged on "sanctuary cities" (Bauder, 2017) and "villes d'accueil" (Bontemps et al., 2018). Since urban governments are often confronted with the consequences of exclusionary national policies, they may tend to adopt more inclusive policies vis-à-vis migrants. From that perspective, the Citizen Platform can perhaps be understood as a rather unique illustration of this argument. Due to the high profile of the migrants' situation, the presence of a larger pool of potential volunteers, and a local government willing to support them, the Citizen Platform found itself in a climate that was favourable to the professionalisation of their services. In that sense a metropolis such as Brussels seems to act as a fruitful space for crafting solidarity.

\section{Acknowledgments}

None of this research would have been possible without the support, openness and generosity of my interlocutors at the Gastvrij Netwerk and the Plateforme Citoyenne. I am also grateful to two institutions for their financial support: the Flemish Research Council (FWO) and an Early Career Fellowship in Refugee and Forced Migration Studies funded by the Swiss Department of Foreign Affairs.

\section{Conflict of Interests}

The author declares no conflict of interests.

\section{References}

Adam, I. (2013). Immigrant integration policies of the Belgian regions: Sub-state nationalism and policy divergence after devolution. Regional \& Federal Studies, 23(5), 547-569.

Alcalde, J., \& Portos, M. (2018). Scale shift and transnationalisation within refugees' solidarity activism. From Calais to the European level. In D. Della Porta (Ed.), Solidarity mobilizations in the 'refugee crisis': Contentious moves (pp. 243-270). New York, NY: Springer.

Ataç, I., Rygiel, K., \& Stierl, M. (2016). The contentious politics of refugee and migrant protest and solidarity movements: Remaking citizenship from the margins. Citizenship Studies, 20(5), 527-544.

Bauder, H. (2017). Sanctuary cities: Policies and practices in international perspective. International Migration,
55(2), 174-187.

Bontemps, V., Makaremi, C., \& Mazouz, S. (eds.) (2018). Entre accueil et rejet Ce que les villes font aux migrants [Between reception and rejection: What cities do for/to migrants]. Lyon: Le passager clandestin.

Bousetta, H., Favell, A., \& Martiniello, M. (2018). Governing multicultural Brussels: Paradoxes of a multilevel, multi-cultural, multi-national urban anomaly. Journal of Ethnic and Migration Studies, 44(12), 2070-2085.

Della Porta, D. (Ed.). (2018). Solidarity mobilizations in the 'refugee crisis': Contentious moves. New York, NY: Springer.

Depraetere, A., \& Oosterlynck, S. (2017). 'I finally found my place': A political ethnography of the Maximiliaan refugee camp in Brussels. Citizenship Studies, 21(6), 693-709.

Deprez, I., Platteau, E., \& Hondeghem, A. (2018). De invulling en versterking van de regierol van lokale besturen op vlak van integratiebeleid [The concretisation and reinforcement of the directing role of local governance with respect to integration policy]. Leuven: KU Leuven Instituut voor de overheid.

Diani, M., \& McAdam, D. (Eds.). (2003). Social movements and networks: Relational approaches to collective action. Oxford: Oxford University Press.

Edwards, B., McCarthy, J. D., \& Mataic, D. R. (2018). The resource context of social movements. In D. A. Snow, S. A. Soule, H. Kriesi, \& H. J. McCammon (Eds.), The Blackwell companion to social movements (pp. 79-97). Oxford: Blackwell.

Fedasil. (2015). Balans 2014 [Balance 2014]. Brussels: Fedasil. Retrieved from www.fedasil.be/sites/ default/files/content/download/files/jaarverslag_ 2014.pdf

Fedasil. (2016). Balans 2015. Opvang van asielzoekers en vrijwillige terugkeer [Balance 2015. Accommodation of asylum seekers and voluntary return]. Brussels: Fedasil. Retrieved from https://www.fedasil.be/ sites/default/files/fedasil_balans_2015_2.pdf

Fedasil. (2017). Balans 2016. Opvang van asielzoekers en vrijwillige terugkeer [Balance 2016 Accommodation of asylum seekers and voluntary return]. Brussels: Fedasil. Retrieved from www.fedasil.be/sites/ default/files/jaarverslag_2016_0_0.pdf

Fedasil. (2018). Sluiting OCMW-plaatsen. Press statement on 29/06/18 [Closure of LAl-residencies]. Brussels: Fedasil. Retrieved from www.fedasil.be/nl/ nieuws/opvang-asielzoekers/sluiting-ocmw-plaatsen

Feischmidt, M., \& Zakaria, A. (2019). Politics of care and compassion: Civic help for refugees and its political implications in Hungary. A mixed-methods approach. In M. Feischmidt, L. Pries, \& C. Cantat (Eds.), Refugee protection and civil society in Europe (pp. 59-99). London: Palgrave MacMillan.

Goeman, H., \& Van Puymbroeck, N. (2011). De bestuurlijke complexiteit van het migrantenbeleid: Conceptuele, institutionele en operationale schets [The 
governance complexity of migration policy: A conceptual, institutional and operational sketch]. In C. Timmerman (Ed.), Mintegratie: Over nieuwe vormen van migratie en integratie [Mintegration: On new forms of migration and integration] (pp. 47-84). Brussels: VUB Press.

Groffy, L., \& Debruyne, P. (2014). Integratie is dood, lang leve de integratie. Van integratiepioniers naar migratiebeheer in superdiverse tijden [Integration is dead, long live integration. From integration pioneers to migration management in the era of superdiversity]. Oikos, 69(2), 44-64.

Jasper, J. M. (1997). The art of moral protest: Culture, biography and creativity in social movements. Chicago, IL: Chicago University Press.

Jasper, J. M. (2014). Protest: A cultural introduction to social movements. Oxford: John Wiley and Sons.

Jasper, J. M., \& Poulsen, J. D. (1995). Recruiting strangers and friends: Moral shocks and social networks in animal rights and anti-nuclear protests. Social Problems, 42(4), 493-512.

Joppke, C. (2007). Beyond national models: Civic integration policies for immigrants in Western Europe. West European Politics, 30(1), 1-22.

Karakayali, S., \& Kleist, J. O. (2016). Strukturen und Motive der ehrenamtlichen Flüchtlingsarbeit (EFA) in Deutschland. 2. Forschungsbericht. Ergebnisse einer explorativen Umfrage vom November/Dezember 2015 [Structures and motivations of unpaid refugee work in Germany. Research report. Results of an exploratory survey from November/December 2015]. Berlin: Berliner Instituts für empirische Integrationsund Migrationsforschung (BIM).

Lafaut, D., \& Coene, G. (2018). "Let them in!" Humanitarian work as political activism? The case of the Maximiliaan refugee camp in Brussels. Journal of Immigrant and Refugee Studies, 17(2), 1-19.

Martiniello, M. (2013). Immigrant integration and multiculturalism in Belgium. In R. Tayas (Ed.), Challenging multiculturalism: European models of diversity ( $\mathrm{pp}$. 120-137). Edinburgh: Edinburgh University Press.

Médecins du Monde. (2018). Politiegeweld tegen vluchtelingen en migranten onderweg in België [Police violence against refugees and migrants en route in Belgium]. Brussels: Médecins du Monde. Retrieved from https://doktersvandewereld.be/system/files/ publications/downloads/MdM\%20rapport\%20 Geweldmigratie\%20NL\%20HDfinal.pdf

Médecins Sans Frontières. (2019). Vlucht zonder einde. Psychische hulp in de humanitaire hub [Flight without ending. Psychological support in the humanitarian hub]. Geneva: Médecins Sans Frontières. Retrieved from https://www.msf-azg.be/sites/default/ files/imce/Rapport\%20humanitaire\%20hub.pdf

Melucci, A. (1989). Nomads of the present: Social movements and individual needs in contemporary society. London: Vintage.

Pries, L. (2018). Refugees, civil society and the State. Euro- pean experiences and global challenges. Cheltenham: Edward Elgar Publishing.

Saeys, A., Vandevoordt, R., \& Verschraegen, G. (2018). Samenleven in diversiteit: kwalitatief onderzoek naar de perspectieven van vluchtelingen [Living in diversity: A qualitative research on the perspectives of refugees]. Brussels: Agentschap Binnenlands Bestuur.

Schinkel, W., \& Van Houdt, F. (2010). The double helix of cultural assimilationism and neo-liberalism: Citizenship in contemporary governmentality. The British Journal of Sociology, 61(4), 696-715.

Snow, D. A., Zurcher, L. A., \& Ekland-Olson, S. (1980). Social networks and social movements: A microstructural approach to differential recruitment. American Sociological Review, 45(5), 787-801.

Swerts, T., \& Oosterlynck, S. (2018). Local civil society dynamics in territorially stigmatized neighbourhoods. The case of Molenbeek, Brussels. Paper presented at USI Lunch Seminar, Antwerp.

Tarrow, S. (2011). Power in movement: Social movements and contentious politics. Cambridge: Cambridge University Press.

Van Dyk, S., \& Misbach, E. (2016). Zur politischen Ökonomie des Helfens [On the political economy of helping]. PROKLA, 46(183), 205-227.

Van Puymbroeck, N., Blondeel, P., \& Vandevoordt, R. (2014). Does Antwerp belong to everyone? Unveiling the conditional limits to inclusive urban citizenship. Social Inclusion, 2(3), 18-28.

Van Puymbroeck, N., \& Saeys, A. (2014). Nationalisme in de integratiesector: Een process van verstatelijking en centralisering [Nationalism in the integration sector: A process of statisation and centralisation]. In G. Verschraegen, C. de Olde, S. Oosterlynck, \& F. Vandermoere (Eds.), Over gevestigden en buitenstaanders. Armoede, diversiteit en stedelijkheid [On the established and outsiders. Poverty, diversity and urbanity] (pp. 187-206). Leuven: Acco.

Vandevoordt, R. (in press-a). A moral personal shelter. How citizens are hosting migrants in and around Brussels. In M. Breeze \& T. Scott-Smith (Eds.), Structures of protection. Oxford: Berghahn Books.

Vandevoordt, R. (in press-b). Subversive humanitarianism. Rethinking the politics of refugee solidarity through grassroots initiatives. Refugee Survey Quarterly.

Vandevoordt, R., \& Verschraegen, G. (2019). Subversive humanitarianism and its challenges: Notes on the political ambiguities of civil refugee support. In M. Feischmidt, L. Pries, \& C. Cantat (Eds.), Refugee protection and civil society in Europe (pp. 101-128). Basingstoke: Palgrave Macmillan.

Vluchtelingenwerk Vlaanderen. (2019). Migranten op doortocht in België. Aanbevelingen voor een meer menselijke aanpak [Migration moving through Belgium. Recommendations for a more humane approach]. Vluchtelingenwerk. Retrieved from https:// 
www.vluchtelingenwerk.be/sites/default/files/ jan2019_migranten_op_doortocht_in_belgie_0.pdf

Walgrave, S. (1994). Nieuwe sociale bewegingen in Vlaanderen [New social movements in Flanders]. Leuven:
KU Leuven.

Youkhana, E., \& Sutter, O. (2017). Perspectives on the European border regime: Mobilization, contestation and the role of civil society. Social Inclusion, 5(3), 1-6.

\section{About the Author}

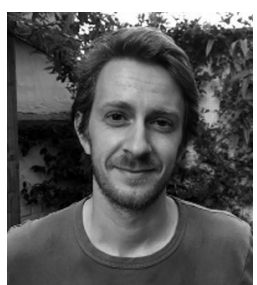

Robin Vandevoordt is a cultural and political sociologist whose research interests are in forced migration, humanitarianism, civil solidarity, and European migration policies. He is currently an Early Career Fellow at Oxford University's Refugee Studies Centre, where he continues his ethnographic work with civil initiatives supporting refugees. He obtained his PhD in Sociology from the University of Antwerp (Belgium) and an MA in Modern Literature from the University of East Anglia (UK). 